\title{
Vibrational analysis of 2,2,3-trichlorobutane and a force field for 2,2-dichloropropane
}

\author{
Sung Hyo Chough* and Samuel Krimm \\ Department of Physics and Macromolecular Research Center, University of Michigan, Ann Arbor, \\ MI 48109, U.S.A.
}

(Received 26 December 1989; in final form and accepted 12 April 1990)

\begin{abstract}
The infrared and Raman spectra of 2,2,3-dichlorobutane have been analysed in terms of normal modes calculated from a force field for secondary dichlorides refined using this molecule as well as 2,2 dichlorobutane and 2,2-dichloropropane. A force field specific to the latter molecule is presented.
\end{abstract}

\section{INTRODUCTION}

IN the previous paper [1], we presented the results of a refinement of a force field for vicinal secondary chlorides, based on vibrational analyses of 2,3,4-trichloropentanes and 2,3-dichlorobutanes. Normal mode analyses showed that the calculated frequencies agreed very well with the observed bands. Such a force field should, therefore, be applicable to structures found in complex chlorinated polymers, such as chlorinated poly(vinyl chloride). However, such systems may also have geminal secondary dichlorides as well as mixtures of these two types. Since it is not simple to analyse for such structures, vibrational spectroscopy can be a very important tool in defining structure in these complex chlorinated hydrocarbons. In order to do this, we need a good force field for the geminal and mixed types of secondary chlorides.

Wu et al. [2] refined force constants related to geminal secondary dichlorides, i.e. $-\mathrm{C}-\mathrm{C}\left(\mathrm{Cl}_{2}\right)-\mathrm{C}-$, in order to interpret the spectra of poly(vinylidene chloride). The model compounds they used were 2,2-dichloropropane and 2,2-dichlorobutane. Their results showed relatively large differences between observed and calculated frequencies for two $\mathrm{C}-\mathrm{C}-\mathrm{C}$ backbone angles that they used, viz. $120^{\circ}$ and tetrahedral.

In order to obtain force constants generally applicable to various secondary chlorides, we synthesized 2,2,3-trichlorobutane and used its spectra in a force field refinement together with 2,2-dichloropropane and 2,2-dichlorobutane. In this refinement we assumed tetrahedral bond angles for all the molecules. The refined force constant set for multiply-chlorinated hydrocarbons is presented in the subsequent paper [3], in the form of a comprehensive force field for various types of secondary chlorides. In this paper we present the force field specific to 2,2-dichloropropane.

\section{EXPERIMENTAL}

2,2,3-Trichlorobutane (2,2,3-TCB) was prepared by the reaction of 2-chloro-3-butanone and $\mathrm{PCl}_{5}[4]$. Phosphorus pentachloride $(0.1 \mathrm{~mole})$ was charged into a three-necked round-bottom flask with a paddle stirrer and reflux condenser, then 2-chloro-3-butanone ( $0.1 \mathrm{~mole})$ was added drop by drop for $2 \mathrm{~h}$ at $60^{\circ} \mathrm{C}$. The reaction was maintained at $60^{\circ} \mathrm{C}$ for $10 \mathrm{~h} .2,2,3-\mathrm{TCB}$ was then obtained by distillation with flowing $\mathrm{N}_{2}$ gas.

Infrared spectra were obtained on a Bomem DA-3 FTIR spectrometer at $2 \mathrm{~cm}^{-1}$ resolution (except for the $500-150 \mathrm{~cm}^{-1}$ region, which was obtained on a Nicolet 60SX FTIR spectrometer). Raman spectra were obtained on a Spex 1403 spectrometer with $\mathrm{Ar}^{+}$laser $514.5 \mathrm{~nm}$ excitation, also at $2 \mathrm{~cm}^{-1}$ resolution.

* Present address: Department of Chemical Engineering, Chonnam National University, Kwangju, Korea 500. 

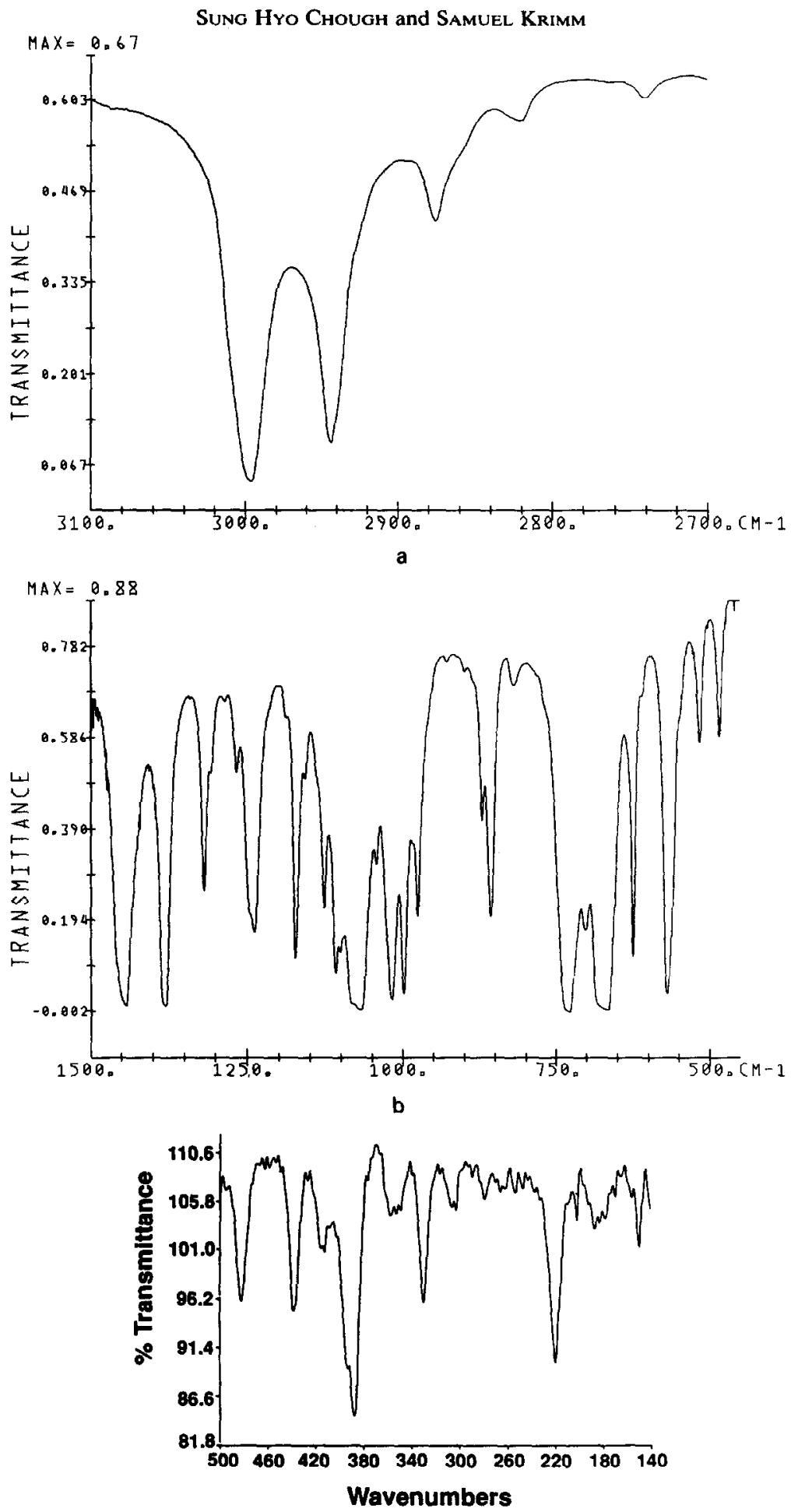

c

Fig. 1. Infrared spectrum of 2,2,3-trichlorobutane in liquid (room temperature) state.

\section{Results and Discussion}

\section{2,2,3-Trichlorobutane}

Infrared spectra of 2,2,3-TCB are given in Fig. 1 and Raman spectra are given in Fig. 2. The observed and calculated frequencies are listed in Tables 1-3. 2,2,3-TCB can have three conformations, trans $(\mathrm{T})$, gauche $(\mathrm{G})$ and gauche ${ }^{\prime}\left(\mathrm{G}^{\prime}\right)$, as shown in Fig. 3 . 

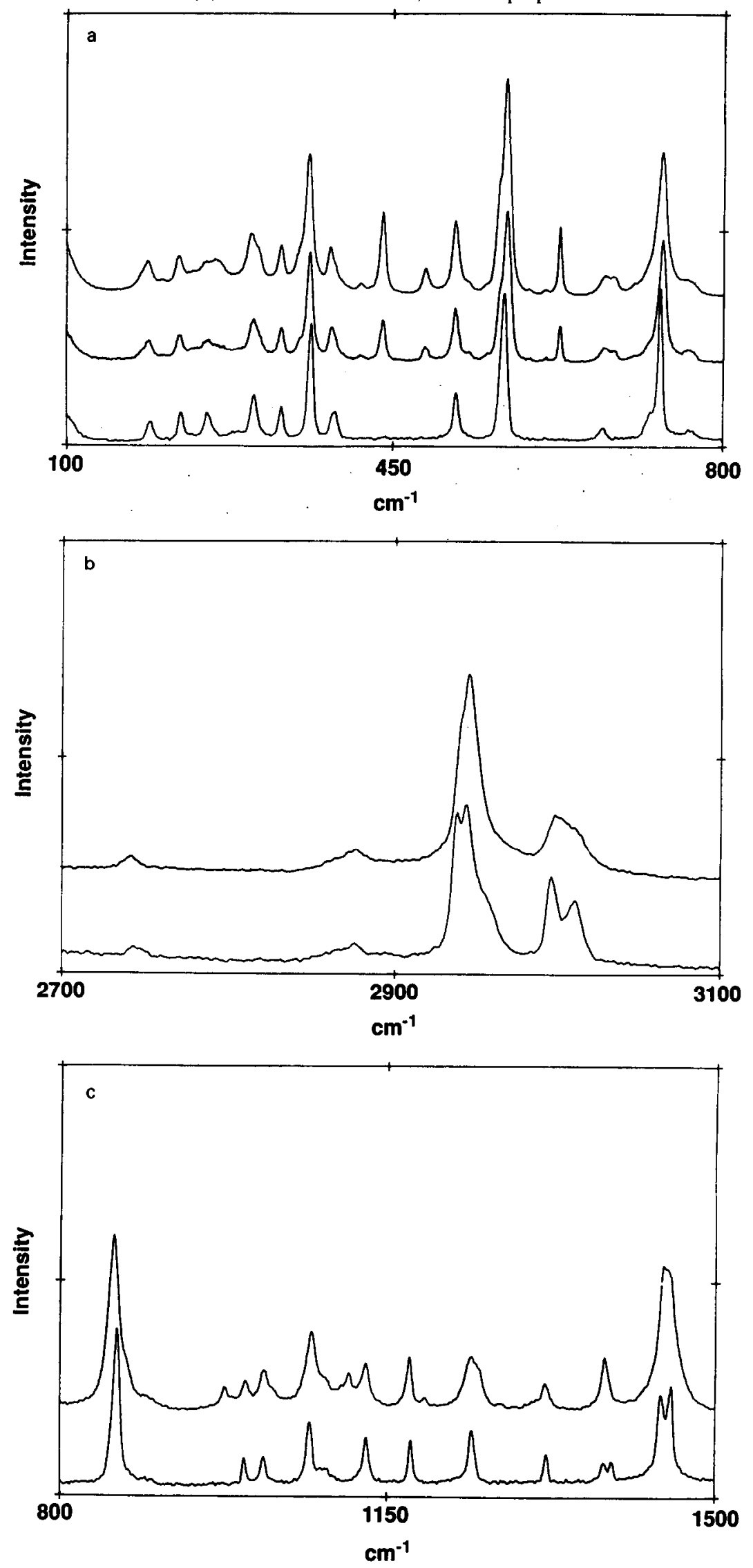

Fig. 2. Raman spectra of 2,2,3-trichlorobutane, in liquid (upper) and solid (lower) states. Middle spectrum in $100-800 \mathrm{~cm}^{-1}$ region is from pre-frozen state. 
Table 1. Observed and calculated frequencies of trans-2,2,3-trichlorobutane

\begin{tabular}{|c|c|c|c|}
\hline \multicolumn{2}{|c|}{ Observed } & \multirow[b]{2}{*}{ Calc. } & \multirow[b]{2}{*}{ Potential energy distribution* } \\
\hline Infrared & Raman & & \\
\hline \multirow{4}{*}{2997 vs } & \multirow{2}{*}{$3009 \mathrm{sh}$} & 2991 & $M$ as1(100) \\
\hline & & 2991 & $M$ as1(90) \\
\hline & \multirow{2}{*}{$2998 \mathrm{mw}$} & 2990 & $M \operatorname{as} 2(90)$ \\
\hline & & 2990 & $M$ as2(99) \\
\hline $2944 \mathrm{~s}$ & $\begin{array}{l}2944 \text { vs } \\
2940 \text { sh }\end{array}$ & 2936 & CH s(99) \\
\hline \multirow{4}{*}{$2875 \mathrm{mw}$} & \multirow{2}{*}{$2877 w$} & 2874 & $M \operatorname{ss}(98)$ \\
\hline & & 2874 & $M \operatorname{ss}(98)$ \\
\hline & \multirow{2}{*}{$1450 \mathrm{sh}$} & 1451 & $M a b 1(65) M a b 2(26)$ \\
\hline & & 1449 & $\mathrm{Mab2(67)} \mathrm{M}$ ab1(25) \\
\hline \multirow{3}{*}{$1446 \mathrm{~s}$} & \multirow{2}{*}{$1444 \mathrm{~s}$} & 1445 & $\mathrm{M}$ ab2(94) \\
\hline & & 1443 & $\mathrm{M}$ ab1(93) \\
\hline & $1389 \mathrm{sh}$ & 1380 & $\mathrm{M} \mathrm{sb}(98) \mathrm{CC} \mathrm{s}(10)$ \\
\hline $1381 \mathrm{~s}$ & $1382 \mathrm{mw}$ & 1376 & $\mathrm{M} \mathrm{sb}(92)$ \\
\hline $1318 \mathrm{~m}$ & $1319 w$ & 1320 & $\mathrm{CH} \mathrm{ob}(51) \mathrm{CC} \mathrm{s}(21) \mathrm{CH} \mathrm{ib}(14)$ \\
\hline $1238 \mathrm{~ms}$ & $1239 \mathrm{mw}$ & 1249 & $\mathrm{CH}$ ib(72) $\mathrm{CH} \mathrm{ob(17)}$ \\
\hline $1173 \mathrm{~ms}$ & $1174 \mathrm{mw}$ & 1173 & $\mathrm{CC} \mathrm{s}(67) \mathrm{Mr} 1(16) \mathrm{CX}_{2} \mathrm{w}(13)$ \\
\hline $1126 \mathrm{~m}$ & $1126 \mathrm{mw}$ & 1130 & $\mathrm{CC} \mathrm{s}(34) \mathrm{M} \mathrm{r1(33)} \mathrm{CX}_{2} \operatorname{def}(12)$ \\
\hline $1068 \mathrm{~s}$ & $1067 \mathrm{~m}$ & 1069 & $\mathrm{CC} \mathrm{s}(54) \mathrm{M} \mathrm{r} 2(24)$ \\
\hline $1025 \mathrm{sh}$ & $1028 \mathrm{vw}$ & 1030 & $\mathrm{Mr}(53) \mathrm{Mr}(24) \mathrm{CX}_{2} \mathrm{r}(10)$ \\
\hline $1017 \mathrm{~s}$ & $1019 \mathrm{~m}$ & 1011 & $\mathrm{Mr} 1(45) \mathrm{CC} \mathrm{s}(23) \mathrm{M} \mathrm{r} 2(20)$ \\
\hline $997 \mathrm{~ms}$ & $998 w$ & 994 & $\mathrm{M}$ r2(71) \\
\hline $856 \mathrm{~ms}$ & $857 \mathrm{~s}$ & 855 & $\mathrm{CC} s(58) \mathrm{M} r 1(41)$ \\
\hline 732 vs & $733 \mathrm{~s}$ & 727 & $\mathrm{CX}_{2} \mathrm{r}(52) \mathrm{CX}_{2}$ as(49) $\mathrm{CX}$ ib(20) $\mathrm{CX} \mathrm{s}(13)$ \\
\hline 668 vs & $672 w$ & 668 & $\mathrm{CXs}(60) \mathrm{CX}_{2}$ as $(20) \mathrm{CX}_{2} \mathrm{ss}(10)$ \\
\hline $569 s$ & $570 \mathrm{vs}$ & 565 & $\mathrm{CX}_{2} \mathrm{ss}(52) \mathrm{CX}_{2}$ as $(32) \mathrm{CX}_{2} \mathrm{~b}(11)$ \\
\hline $516 \mathrm{mw}$ & $515 \mathrm{~m}$ & 516 & $\mathrm{CX} \mathrm{ib(27)} \mathrm{CX}_{2} w(18) \mathrm{CC}$ s(16) CHX def(11) \\
\hline $390 \mathrm{~m}$ & $388 \mathrm{w}$ & 387 & $\mathrm{CX}$ ob(29) $\mathrm{CX}_{2} \mathrm{w}(22) \mathrm{CX}_{2} \operatorname{def}(22)$ \\
\hline $358 w$ & $361 \mathrm{~s}$ & 362 & $\mathrm{CX} \mathrm{s(21)} \mathrm{CX}_{2}$ as(17) $\mathrm{CX}_{2} \mathrm{ss}(11)$ \\
\hline $330 \mathrm{mw}$ & $331 \mathrm{w}$ & 325 & $\mathrm{CX}_{2} \mathrm{tw}(39) \mathrm{CCr}(34)$ \\
\hline \multirow[t]{3}{*}{$305 \mathrm{w}$} & $300 \mathrm{mw}$ & 287 & $\mathrm{CX}_{2} \mathrm{~b}(64) \mathrm{CX}_{2} \mathrm{ss}(16)$ \\
\hline & $255^{4} \mathrm{sh}$ & 275 & $\mathrm{MC}$ tor(99) \\
\hline & $252 w$ & 272 & $\mathrm{MC}$ tor $(91)$ \\
\hline \multirow[t]{2}{*}{$220 \mathrm{mw}$} & $223 w$ & 226 & CX ob(35) $\mathrm{CX}_{2} \mathrm{tw}(26) \mathrm{CX}_{2} \mathrm{w}(14) \mathrm{CX}_{2} \operatorname{def}(14)$ \\
\hline & & & $\mathrm{CX}_{2} \mathrm{~b}(13) \mathrm{CHX} \operatorname{def}(11)$ \\
\hline \multirow[t]{3}{*}{$187 w$} & $188 w$ & 192 & CHX $\operatorname{def}(28) \mathrm{CX}$ ib(26) CX 2 w(24) $\mathrm{CX}_{2} \operatorname{def}(18)$ \\
\hline & & 173 & $\begin{array}{l}\mathrm{CX}_{2} \operatorname{def}(34) \mathrm{CX} \text { ob(16) } \mathrm{CHX} \operatorname{def}(15) \mathrm{CX}_{2} \mathrm{r}(14) \\
\mathrm{CX}_{2} \text { tw(13) }\end{array}$ \\
\hline & & 79 & $\mathrm{CC}$ tor $(96)$ \\
\hline
\end{tabular}

${ }^{*}$ s, stretch; as, antisymmetric stretch; ss, symmetric stretch; $b$, bend; $a b$, antisymmetric bend; sb, symmetric bend; ib, in-plane bend; ob, out-of-plane bend; dęf, deformation; w, wag; r, rock; tw, twist; tor, torsion (see [3] for definition of these local symmetry coordinates). $\mathrm{M}=$ methyl, $\mathrm{X}=\mathrm{Cl}$. Contribution to the PED of 10 or larger.

${ }^{+}$Visible in the solid state.

Our MM2 calculated cnergies of the three conformers were $10.73 \mathrm{kcal} \mathrm{mol}^{-1}$ for $\mathrm{T}$, $11.78 \mathrm{kcal} \mathrm{mol}^{-1}$ for $\mathrm{G}$, and $13.23 \mathrm{kcal} \mathrm{mol}^{-1}$ for $\mathrm{G}^{\prime}$. On solidifying the sample, some bands disappear and others become sharper, the frequency shifts being small. The frequencies for the $\mathrm{T}$ isomer are taken as the liquid state frequencies that remain in the solid state Raman spectrum. In order to assign the bands for $G$ and $G^{\prime}$ conformations, intensity changes in the spectra were observed at various temperatures down to freezing. We expected that the intensities of some bands that are uniquely assignable to $G$ or $G^{\prime}$ might change at low temperatures due to the energy difference between these conformers. However, there were no significant changes to distinguish the $G$ and $G^{\prime}$ conformations, even though very different frequencies are associated with them. These 
Table 2. Observed and calculated frequencies of gauche-2,2,3-trichlorobutane

\begin{tabular}{|c|c|c|c|}
\hline \multicolumn{2}{|c|}{ Observed } & \multirow[b]{2}{*}{ Calc. } & \multirow[b]{2}{*}{ Potential energy distribution* } \\
\hline Infrared & Raman & & \\
\hline \multirow{4}{*}{2997 vs } & \multirow{2}{*}{$3009 \mathrm{sh}$} & 2991 & $M$ as1(96) \\
\hline & & 2991 & $M$ as1(97) \\
\hline & \multirow{2}{*}{$2998 \mathrm{~m}$} & 2990 & $M$ as2(92) \\
\hline & & 2990 & $\mathrm{M}$ as2(98) \\
\hline $2944 \mathrm{~s}$ & $\begin{array}{l}2944 \text { vs } \\
2940 \mathrm{sh}\end{array}$ & 2937 & $\mathrm{CH} \mathbf{s}(99)$ \\
\hline \multirow{4}{*}{$2875 \mathrm{mw}$} & \multirow{2}{*}{$2877 \mathrm{mw}$} & 2874 & M ss(99) \\
\hline & & 2874 & M ss(99) \\
\hline & \multirow{2}{*}{$1450 \mathrm{sh}$} & 1451 & $M$ ab1(67) $M$ ab2(24) \\
\hline & & 1449 & $\mathrm{M} a b 2(68) \mathrm{M} a b 1(23)$ \\
\hline \multirow{2}{*}{$1446 \mathrm{~s}$} & \multirow{2}{*}{$1444 \mathrm{~s}$} & 1445 & $\mathrm{M}$ ab2(94) \\
\hline & & 1443 & $\mathrm{Mabl}(92)$ \\
\hline \multirow{2}{*}{$1381 \mathrm{~s}$} & \multirow{2}{*}{$1382 \mathrm{mw}$} & 1380 & $\mathrm{M} \operatorname{sb}(98) \mathrm{CC} s(10)$ \\
\hline & & 1375 & $\mathrm{M} \mathrm{sb}(95)$ \\
\hline $1310 \mathrm{sh}$ & $1307^{\dagger} \mathrm{vw}$ & 1309 & $\mathrm{CH}$ ob(53) $\mathrm{CH} \mathrm{ib}(20) \mathrm{CCs}(15)$ \\
\hline $1246 \mathrm{sh}$ & $1246^{\dagger} \mathrm{sh}$ & 1251 & $\mathrm{CH}$ ib(61) $\mathrm{CH}$ ob(24) \\
\hline $1190 \mathrm{vw}$ & $1191^{\dagger} w$ & 1189 & $\mathrm{CC} \mathrm{s}(40) \mathrm{M} \mathrm{r1}(16) \mathrm{M} r 2(15) \mathrm{CX} \mathrm{ib}(12)$ \\
\hline $1108 \mathrm{~m}$ & $1109^{\dagger} w$ & 1106 & $\mathrm{CC} \mathrm{s(40)} \mathrm{M} \mathrm{rl(16)} \mathrm{M} \mathrm{r2(15)} \mathrm{CX} \mathrm{ib(12)}$ \\
\hline $1080 \mathrm{sh}$ & $1083 \mathrm{sh}$ & 1071 & $\mathrm{CC} \mathrm{s}(42) \mathrm{M} \mathrm{r1}(20)$ \\
\hline \multicolumn{2}{|l|}{$1045 \mathrm{w}$} & 1035 & M r2(54) M r1(20) \\
\hline $997 \mathrm{~ms}$ & $998 w$ & 1005 & $\mathrm{M}$ r2(75) M r1(14) \\
\hline $975 \mathrm{~m}$ & $977^{+} \mathrm{w}$ & 964 & $\mathrm{CC} \mathrm{s(36)} \mathrm{M} \mathrm{r2(23)} \mathrm{CH} \mathrm{ob(19)} \mathrm{M} \mathrm{r1(18)}$ \\
\hline $871 w$ & $871^{+} \mathrm{sh}$ & 866 & $\mathrm{CC} \mathrm{s}(59) \mathrm{M} \mathrm{r1}(32) \mathrm{CX}_{2} \mathrm{ss}(10)$ \\
\hline 732 vs & $733 \mathrm{~s}$ & 737 & $\mathrm{CX}_{2}$ as (53) $\mathrm{CX}_{2} \mathrm{r}(48) \mathrm{CHX} \operatorname{def}(26) \mathrm{CX} s(16)$ \\
\hline $681 \mathrm{sh}$ & $681^{\dagger} w$ & 672 & $\mathrm{CXs}(58) \mathrm{CX}_{2}$ as $(32)$ \\
\hline $624 \mathrm{~s}$ & $625^{\dagger} \mathrm{m}$ & 624 & $\mathrm{CX}_{2} \operatorname{ss}(44) \mathrm{CX}_{2} \operatorname{def}(26) \mathrm{CX}$ ib (26) \\
\hline $439 \mathrm{mw}$ & $439^{\dagger} \mathrm{m}$ & 437 & $\mathrm{CX} \mathrm{ib}(23) \mathrm{CX}_{2} \mathrm{ss}(21) \mathrm{CX}$ def(10) \\
\hline $390 \mathrm{~m}$ & $388 w$ & 389 & $\mathrm{CX}_{2} \mathrm{w}(52) \mathrm{CX}$ ob(22) $\mathrm{CX}_{2} \mathrm{ss}(11)$ \\
\hline $349 w$ & $348^{\dagger} \mathrm{sh}$ & 358 & $\mathrm{CX}_{2}$ as (27) $\mathrm{CX}_{2} \mathrm{r}(17) \mathrm{CX} \mathrm{s}(15) \mathrm{CHX} \operatorname{def}(10)$ \\
\hline \multirow{3}{*}{305} & $307^{\dagger} \mathrm{sh}$ & 303 & $\mathrm{CX}_{2}$ tw(36) CHX def(24) $\mathrm{CX}_{2} \mathrm{r}(15) \mathrm{CX}_{2} \mathrm{~b}(12)$ \\
\hline & $300 \mathrm{mw}$ & 297 & $\mathrm{CX}_{2} \mathrm{~b}(34) \mathrm{CX}_{2} \operatorname{tw}(24) \mathrm{CX}_{2} \mathrm{ss}(15) \mathrm{CX}$ ob(11) \\
\hline & $267^{\dagger} w$ & 275 & $\mathrm{MC}$ tor(97) \\
\hline $266 \mathrm{vw}$ & $261^{\dagger} w$ & 274 & $\mathrm{MC} \operatorname{tor}(81)$ \\
\hline $247 v w$ & $247^{\dagger} w$ & 245 & $\begin{array}{l}\mathrm{CX} \text { ib(26) } \mathrm{CX}_{2} \operatorname{def}(20) \mathrm{CX}_{2} \mathrm{w}(14) \mathrm{CX} \text { ob(13) } \\
\mathrm{CX}_{2} \mathrm{~b}(11) \mathrm{MC} \text { tor(10) }\end{array}$ \\
\hline $203 w$ & $204^{\dagger} \mathrm{vw}$ & 203 & $\begin{array}{l}\mathrm{CX}_{2} \operatorname{def}(47) \mathrm{CX}_{2} \mathrm{~b}(21) \mathrm{CHX} \operatorname{def}(19) \mathrm{CX} \text { ob(16) } \\
\quad \mathrm{CX} \text { ib(13) } \mathrm{CX}_{2} \operatorname{tw}(10)\end{array}$ \\
\hline \multirow[t]{2}{*}{$179 w$} & \multirow[t]{2}{*}{$181^{\dagger} \mathrm{sh}$} & 170 & $\begin{array}{l}\mathrm{CX}_{2} \mathrm{r}(23) \mathrm{CX}_{2} \mathrm{tw}(21) \mathrm{CHX} \operatorname{def}(19) \mathrm{CX} \text { ob(18) } \\
\quad \mathrm{CX}_{2} \operatorname{def}(12)\end{array}$ \\
\hline & & 79 & $\mathrm{CC}$ tor $(96)$ \\
\hline
\end{tabular}

* See footnote* of Table 1.

${ }^{\dagger}$ Disappears in the solid state.

spectral results may indicate that the energy difference between the $G$ and $G^{\prime}$ conformers is small, despite the results of the MM2 calculations.

To assign the bands of $\mathrm{G}$ and $\mathrm{G}^{\prime}$, we first refined the force field using the trans form of 2,2,3-TCB, 2,2-dichloropropane (2,2-DCPr), and the trans and gauche forms of 2,2dichlorobutane $(2,2-\mathrm{DCB})$. The starting force constants were transferred from our previously refined force field as well as those of Wu et al. [2]. From the normal mode calculations based on these refined force constants, the bands in the $400-700 \mathrm{~cm}^{-1}$ region that disappear on solidification could be uniquely assigned to the $G$ and $G^{\prime}$ conformations. Finally, with all bands assigned to $T, G$ and $G^{\prime}$ conformations of 2,2,3-TCB, to 2,2-DCPr, and to $T$ and $G$ conformations of 2,2-DCB, we refined the combined force constant set again.

Trans-2,2,3-trichlorobutane. Observed and calculated frequencies of trans-2,2,3-TCB are listed in Table 1 together with their potential energy distributions (PED). 
Table 3. Observed and calculated frequencies of gauche' $-2,2,3$-trichlorobutane

\begin{tabular}{|c|c|c|c|}
\hline \multicolumn{2}{|c|}{ Observed } & \multirow[b]{2}{*}{ Calc. } & \multirow[b]{2}{*}{ Potential energy distribution* } \\
\hline Infrared & Raman & & \\
\hline \multirow{4}{*}{2997 vs } & \multirow{2}{*}{$3009 \mathrm{sh}$} & 2991 & $\mathrm{M}$ as1(99) \\
\hline & & 2991 & $M$ as1(90) \\
\hline & \multirow{2}{*}{$2998 \mathrm{~m}$} & 2990 & $\mathrm{M}$ as2(87) $\mathrm{M}$ asl(10) \\
\hline & & 2990 & $M$ as2(99) \\
\hline $2944 \mathrm{~s}$ & $\begin{array}{l}2944 \text { vs } \\
2940 \text { sh }\end{array}$ & 2937 & $\mathrm{CH} \mathrm{s}(99)$ \\
\hline \multirow{4}{*}{$2875 \mathrm{mw}$} & \multirow{2}{*}{$2877 \mathrm{mw}$} & 2874 & M ss(99) \\
\hline & & 2874 & $M \operatorname{ss}(100)$ \\
\hline & \multirow{2}{*}{$1450 \mathrm{sh}$} & 1451 & $\mathrm{M} a b 1(66) \mathrm{M} \mathrm{ab2(25)}$ \\
\hline & & 1449 & $\mathrm{M}$ ab2(68) M ab1(24) \\
\hline $1446 \mathrm{~s}$ & \multirow{2}{*}{$1444 s$} & 1445 & $\mathrm{M}$ ab2(94) \\
\hline \multirow[b]{2}{*}{$1381 \mathrm{~s}$} & & 1443 & M ab1(91) \\
\hline & $1382 \mathrm{mw}$ & 1380 & M sb(93) \\
\hline $1310 \mathrm{sh}$ & $1307^{\dagger} \mathrm{vw}$ & 1314 & $\begin{array}{l}\mathrm{CH}(90) \\
\mathrm{CH} \mathrm{ob}(52) \mathrm{CH} \text { ib(17) } \mathrm{CC} \mathrm{s}(22)\end{array}$ \\
\hline $1246 \mathrm{sh}$ & $1244^{\dagger} \mathrm{sh}$ & 1249 & $\mathrm{CH}$ ib(69) $\mathrm{CH}$ ob(20) \\
\hline $1173 \mathrm{~ms}$ & $1174 \mathrm{mw}$ & 1179 & $\mathrm{CC} \mathrm{s}(57) \mathrm{M} \mathrm{r1}(24)$ \\
\hline $1108 \mathrm{~m}$ & $1109^{\dagger} w$ & 1105 & $\mathrm{CC} s(69)$ \\
\hline $1100 \mathrm{vw}$ & $1101^{+}$vw & 1090 & $\mathrm{CCs}$ (35) M r2(26) CX ob(11) M r1(11) \\
\hline $1045 \mathrm{w}$ & & 1036 & $\mathrm{Mr1}(39) \mathrm{Mr} 2(22) \mathrm{CC} s(15)$ \\
\hline $997 \mathrm{~ms}$ & $998 w$ & 1006 & $\mathrm{M} \mathrm{r2(66)} \mathrm{M} \mathrm{r1(15)} \mathrm{CC} \mathrm{s(11)}$ \\
\hline $975 \mathrm{~m}$ & $977^{\dagger} \mathrm{w}$ & 988 & $\mathrm{M} \mathrm{r} 2(51) \mathrm{M} \mathrm{r} 1(37)$ \\
\hline \multirow[t]{2}{*}{$871 w$} & $871^{\dagger} \mathrm{sh}$ & 877 & $\mathrm{CCs}(51) \mathrm{M} \mathrm{r} 1(20)$ \\
\hline & $721 w$ & 723 & $\mathrm{CX}_{2} \operatorname{as}(64) \mathrm{CX}_{2} \mathrm{r}(48) \mathrm{CX} \mathrm{ib}(17)$ \\
\hline \multirow[t]{2}{*}{$699 w$} & & 687 & $\mathrm{CXs}(61) \mathrm{CHX} \operatorname{def}(23) \mathrm{CX}_{2} \operatorname{def}(18)$ \\
\hline & $562^{\dagger} \mathrm{sh}$ & 558 & $\mathrm{CX}_{2} \mathrm{ss}(60) \mathrm{CX}_{2}$ as $(23) \mathrm{CX}_{2} \mathrm{~b}(14)$ \\
\hline $482 \mathrm{mw}$ & $484^{\dagger} \mathrm{w}$ & 471 & $\mathrm{CX}_{2} \mathrm{w}(22) \mathrm{CX} \mathrm{s}(19) \mathrm{CX}$ ib(16) $\mathrm{CX}_{2}$ as(11) \\
\hline $413 w$ & $415^{\dagger} \mathrm{vw}$ & 411 & $\mathrm{CX} \mathrm{ob}(31) \mathrm{CX}_{2} \mathrm{w}(16) \mathrm{CX}_{2}$ as (13) \\
\hline $353 w$ & & 351 & CHX def(20) CX s(16) CX 2 def(15) CX ob(12) \\
\hline $330 \mathrm{mw}$ & $331 \mathrm{w}$ & 326 & $\mathrm{CX}_{2} \mathrm{tw}(46) \mathrm{CX}_{2} \mathrm{r}(40)$ \\
\hline \multirow[t]{2}{*}{$279 \mathrm{vw}$} & & 285 & $\mathrm{CX}_{2} \mathrm{~b}(63) \mathrm{CX}_{2} \mathrm{ss}(16)$ \\
\hline & $267^{\dagger} w$ & 275 & $\mathrm{MC} \operatorname{tor}(93)$ \\
\hline $266 \mathrm{vw}$ & $261^{\dagger} w$ & 274 & $\mathrm{MC} \operatorname{tor}(82)$ \\
\hline $247 \mathrm{vw}$ & $247^{\dagger} w$ & 242 & $\begin{array}{l}\mathrm{CX}_{2} \operatorname{def}(32) \mathrm{CHX} \operatorname{def}(25) \mathrm{CX} \text { ob(18) } \mathrm{CX}_{2} \mathrm{~b}(18) \\
\mathrm{CX}_{2} \mathrm{w}(12)\end{array}$ \\
\hline $187 w$ & $188 w$ & 187 & $\mathrm{CX}_{2}$ tw(31) CX ib(31) $\mathrm{CX}_{2} \mathrm{r}(21) \mathrm{CHX} \operatorname{def}(16)$ \\
\hline \multirow[t]{2}{*}{$179 w$} & $181^{\dagger} \mathrm{sh}$ & 173 & $\mathrm{CX}_{2} \operatorname{def}(32) \mathrm{CX}$ ob(23) $\mathrm{CX}_{2} w(19) \mathrm{CHX} \operatorname{def}(11)$ \\
\hline & & 77 & $\mathrm{CC}$ tor $(95)$ \\
\hline
\end{tabular}

* See foutnote* of Table 1.

'Disappears in the solid state.

In the $\mathrm{CH}$ stretch (s) region, the antisymmetric (as) and symmetric (ss) stretch modes of the methyl $(\mathrm{M})$ groups are readily assigned in general, as is $(\mathrm{Cl}) \mathrm{CH}$, on the basis of force constants that we refined for other chlorinated hydrocarbons [1]. Of course, small differences may be expected because of the locally different chemical environments. Fermi resonances with overtones and combinations of bending modes are also known to affect this region [5]. In the absence of such a detailed analysis, we have not modified this part of the force field.

The antisymmetric (ab) and symmetric ( $\mathrm{sb}$ ) $\mathrm{M}$ bend modes are well accounted for, as are the $\mathrm{CH}$ in-plane (ib) and out-of-plane (ob) bend and $\mathrm{CC} \mathrm{s}$ modes. It should be noted that the modes calculated at 1320 and $1130 \mathrm{~cm}^{-1}$ are unique to the $T$ conformer. We considered the possibility that the weak $\sim 1080 \mathrm{~cm}^{-1}$ band, present in both liquid and solid, might be a fundamental, but this hypothesis is not supported in the refinement. It seems possible that this band is a combination: $733+361=1094$. Although the $1028 \mathrm{~cm}^{-1}$ band in the Raman weakens on solidification, it still seems to be present in the solid and 
thus may justify our assignment of the $1030 \mathrm{~cm}^{-1}$ mode. The other $\mathrm{M}$ rock (r) and CC s modes are well predicted.

In the $\mathrm{CCl} \mathrm{s}$ region, the symmetric and antisymmetric stretches of $\mathrm{CCl}_{2}$ are coupled with $\mathrm{CCl} \mathrm{s}$ and distributed from 733 to $300 \mathrm{~cm}^{-1}$. A weak band at $721 \mathrm{~cm}^{-1}$, also present in the solid, may be an overtone of a strong band at $361 \mathrm{~cm}^{-1}: 2 \times 363=722 \mathrm{~cm}^{-1}$. In this region, the calculated frequencies are very close to the observed bands, except for that at $\sim 303 \mathrm{~cm}^{-1}$, which is calculated as a mixed bend and symmetric stretch of $\mathrm{CCl}_{2}$ at $287 \mathrm{~cm}^{-1}$. When the latter is brought closer to $303 \mathrm{~cm}^{-1}$, the other $\mathrm{CCl} \mathrm{s}$ bands deviate more. A similar mode in trans-2,2-DCB is observed at $276 \mathrm{~cm}^{-1}$ and calculated at $269 \mathrm{~cm}^{-1}$ (see below). With allowance for the effect of the third $\mathrm{Cl}$ atom adjacent to $\mathrm{CCl}_{2}$, we believe that the band at $303 \mathrm{~cm}^{-1}$ is probably correctly assigned to this mixed mode. It should be noted that the 516 and $565 \mathrm{~cm}^{-1}$ modes are also unique to the $\mathrm{T}$ conformer.

The methyl-carbon torsion (tor) frequencies are difficult to assign: the calculated values are at 275 and $272 \mathrm{~cm}^{-1}$, but the only observed bands in this region are at 279 and $266 \mathrm{~cm}^{-1}$ in the i.r. and a broad band from $\sim 270$ to $250 \mathrm{~cm}^{-1}$ in the Raman. The $279 \mathrm{~cm}^{-1}$ band is most reasonably assigned to the $G^{\prime}$ isomer, while a Raman peak at $\sim 247 \mathrm{~cm}^{-1}$ can be associated with modes of the $G$ and $G^{\prime}$ isomers. Since the broad $270-250 \mathrm{~cm}^{-1}$ Raman band collapses to a sharp band at $252 \mathrm{~cm}^{-1}$ in the solid, we have assigned this band to $\mathrm{MC}$ tor in the T isomer, reserving the disappearing bands at 267 and $261 \mathrm{~cm}^{-1}$ for the $G$ and $G^{\prime}$ structures. If we try to decrease the discrepancy for the $252 \mathrm{~cm}^{-1}$ band in the refinement, torsion frequencies in other molecules become worse. We have therefore left the torsion force constants unchanged, pending further investigations of this region. It should be noted that the $226 \mathrm{~cm}^{-1}$ mode is another one unique to the $T$ conformer.

Gauche- and gauche'-2,2,3-trichlorobutane. The proposed band assignments and calculated frequencies for G-and $\mathrm{G}^{\prime}-2,2,3-\mathrm{TCB}$ are listed in Tables 2 and 3, respectively, with their PEDs. Many bands overlap those of the T conformation, but some are unique to each structure.

For the $\mathrm{G}$ conformation, unique frequencies are found for modes calculated at 1189 , 624,437 and $203 \mathrm{~cm}^{-1}$. These as well as other bands involve specifically predicted large shifts from the frequencies of the $T$ conformer, e.g. 1320-1309, 1173-1189, 1130-1106, 994-964, 565-624, 516-437 and $325-303 \mathrm{~cm}^{-1}$, and these shifts are indeed observed. A similar situation exists for the $G^{\prime}$ conformation, with unique modes calculated at 471 and $411 \mathrm{~cm}^{-1}$ and shifts that are comparable to those of the $\mathrm{G}$ conformer.

In the case of 2,3-dichlorobutane, JING and KRIMM [6] identified the $\mathrm{S}_{\mathrm{HCl}} \mathrm{CCl} \mathrm{s}$ frequency as occuring near $650 \mathrm{~cm}^{-1}$, between $S_{\mathrm{HH}}$ at $\sim 600$ and $S_{\mathrm{HC}}$ at $\sim 690 \mathrm{~cm}^{-1}$. It is interesting to note that in 2,2,3-TCB, while $\mathrm{CCl} \mathrm{s}\left(\mathrm{S}_{\mathrm{HC}}\right)$ for the $\mathrm{G}^{\prime}$ conformer is observed near its expected value, viz. at $699 \mathrm{~cm}^{-1}$, the $S_{\mathrm{HCl}} \mathrm{CCl}$ s frequencies of the $\mathrm{T}$ and $\mathrm{G}$ conformers are found at higher-than-expected frequencies, $668 \mathrm{~cm}^{-1}$ for $T$ and $681 \mathrm{~cm}^{-1}$ for $\mathrm{G}$. This is probably due to the presence of the neighboring $\mathrm{CCl}_{2}$ group in 2,2,3-TCB.

\section{2,2-Dichlorobutane}

2,2-Dichlorobutane has two conformations, $T$ and $\mathrm{G}$. Spectra have been obtained by OHNo et al. [7] and by CROWDER and LiN [8]. The spectra of the T conformer can be

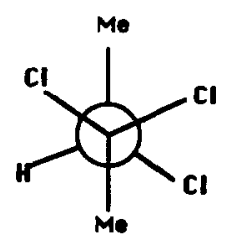

$\mathbf{T}$

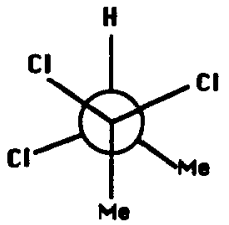

$\mathbf{6}$

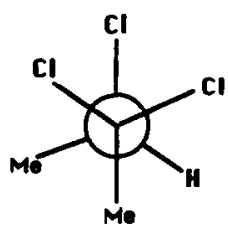

$\mathbf{6}^{\prime}$

Fig. 3. Conformers of 2,2,3-trichlorobutane 
Table 4. Observed and calculated frequencies of trans-2,2dichlorobutane

\begin{tabular}{|c|c|c|c|}
\hline Sym. & Observed* & Calc. & Potential energy distribution $^{\dagger}$ \\
\hline \multirow[t]{21}{*}{$A^{\prime}$} & \multirow{2}{*}{2980} & 2991 & $M$ as1(99) \\
\hline & & 2991 & $M$ as1(99) \\
\hline & \multirow{2}{*}{2866} & 2874 & $\mathrm{M} s \mathrm{ss}(99)$ \\
\hline & & 2874 & M ss(99) \\
\hline & 2848 & 2839 & $\mathrm{CH}_{2} \mathrm{ss}(99)$ \\
\hline & 1463 & 1453 & $\mathrm{M}$ ab1(80) \\
\hline & 1454 & 1443 & $\mathrm{M}$ ab1(92) \\
\hline & 1427 & 1433 & $\mathrm{CH}_{2} \mathrm{~b}(88)$ \\
\hline & \multirow{2}{*}{1382} & 1382 & $\mathrm{M} \mathrm{sb}(93)$ \\
\hline & & 1376 & $\mathrm{M} \mathrm{sb}(91)$ \\
\hline & 1342 & 1330 & $\mathrm{CH}_{2} \mathrm{w}(69) \mathrm{CCs}(16)$ \\
\hline & 1170 & 1163 & $\mathrm{Mrl}(43) \mathrm{CC}$ s(28) CX $2 \operatorname{def}(12)$ \\
\hline & 1120 & 1124 & $M C \cdot s(71) C X_{2} w(19) C C s(18)$ \\
\hline & 1037 & 1028 & $\operatorname{MCs}(85)$ \\
\hline & 999 & 989 & $\mathrm{Mr} 1(66)$ \\
\hline & 859 & 861 & $\mathrm{Mrl}(45) \mathrm{CC} \mathrm{s}(42)$ \\
\hline & 544 & 547 & $C X_{2} s s(81) C X_{2} b(13)$ \\
\hline & 490 & 481 & $\mathrm{CH}_{2} \operatorname{def}(39) \mathrm{CX}_{2} \mathrm{w}(36) \mathrm{MCs}(12)$ \\
\hline & 358 & 348 & $C X_{2} \operatorname{def}(50) C X_{2} w(19)$ \\
\hline & 276 & 269 & $\mathrm{CX}_{2} \mathrm{~b}(80) \mathrm{CX}_{2} \mathrm{ss}(16) \mathrm{CX}_{2} \operatorname{def}(10)$ \\
\hline & 202 & 192 & $\mathrm{CH}_{2} \operatorname{def}(46) \mathrm{CX}_{2} w(34) \mathrm{CX}_{2} \operatorname{def}(23)$ \\
\hline \multirow[t]{15}{*}{$A^{\prime \prime}$} & \multirow{2}{*}{2980} & 2991 & $M$ as2(99) \\
\hline & & 2990 & $M$ as2(99) \\
\hline & 2930 & 2901 & $\mathrm{CH}_{2}$ as $(99)$ \\
\hline & \multirow{2}{*}{1454} & 1449 & $M a b 2(91)$ \\
\hline & & 1445 & M ab2(94) \\
\hline & 1279 & 1288 & $\mathrm{CH}_{2} \mathrm{tw}(58) \mathrm{M} \mathrm{r} 2(14)$ \\
\hline & 1037 & 1040 & $\mathrm{M} \mathrm{r2(44)} \mathrm{CH}_{2} \mathrm{tw}(34) \mathrm{CH}_{2} \mathrm{r}(27)$ \\
\hline & 999 & 1002 & $M r 2(85)$ \\
\hline & 808 & 799 & $\mathrm{CH}_{2} \mathrm{r}(61) \mathrm{M} \mathrm{r} 2(47)$ \\
\hline & 645 & 646 & $\mathrm{CX}_{2}$ as (114) $\mathrm{CX}_{2} \mathrm{r}(56)$ \\
\hline & 358 & 364 & $\mathrm{CX}_{2} \mathrm{r}(66)$ \\
\hline & 276 & 290 & $\mathrm{CX}_{2}$ tw(67) $\mathrm{M}_{1} \mathrm{C}_{2}$ tor(24) \\
\hline & 252 & 271 & $\mathrm{M}_{1} \mathrm{C}_{2}$ tor(75) $\mathrm{CX}_{2} \operatorname{tw}(24)$ \\
\hline & \multirow[t]{2}{*}{202} & 198 & $\mathrm{M}_{4} \mathrm{C}_{3}$ tor $(88)$ \\
\hline & & 120 & $C C \operatorname{tor}(77) C X_{2}$ tw $(13)$ \\
\hline
\end{tabular}

* From [7].

'See footnote* of Table 1.

obtained from the solid sample, while the bands that disappear on solidification are attributable to the $\mathrm{G}$ conformer. The $\mathrm{T}$ conformation has $C_{s}$ symmetry, and the normal modes are divided into 21 modes of $A^{\prime}$ and 15 of $A^{\prime \prime}$ symmetry. The results of our normal mode calculations for the $T$ and $G$ conformations are given in Tables 4 and 5 , respectively.

Wu et al. [2] used normal mode analysis to refine the force constants for both tetrahedral and $120^{\circ} \mathrm{C}-\mathrm{C}-\mathrm{C}$ bond angles, but their results showed large discrepancies with observation. They initially used the spectra assigned by OHNO et al. [7]. However, in the $A^{\prime \prime}$ block for the $\mathrm{T}$ conformation, they assigned the methyl rock mode to a band at $1088 \mathrm{~cm}^{-1}$, which is very weak in the solid sample. OHNO et al. [7] did not assign this band to the T conformer. Recently, CROwDER and LIN [8] also measured the spectra of this molecule, but they did not observe the band at $1088 \mathrm{~cm}^{-1}$ in the solid sample. We assigned the band at $1037 \mathrm{~cm}^{-1}$ to a methyl rock, following OHNO et al. [7], because our preliminary calculations gave $1044 \mathrm{~cm}^{-1}$ for this mode. This is in agreement with the assignment of CROWDER and LIN [8].

In the $\mathrm{CH} s$ region, there is a large discrepancy for the $\mathrm{CH}_{2}$ as mode of the $\mathrm{T}$ conformer. However, when the calculated frequency of $2901 \mathrm{~cm}^{-1}$ was adjusted to come 
Table 5. Observed and calculated frequencies of gauche-2,2dichlorobutane

\begin{tabular}{|c|c|c|}
\hline Observed* & Calc. & Potential energy distribution $^{\dagger}$ \\
\hline \multirow{2}{*}{2980} & 2991 & $M \operatorname{as1}(98)$ \\
\hline & 2991 & $\mathrm{M}$ as2(93) \\
\hline \multirow{2}{*}{2944} & 2991 & $M$ as1(94) \\
\hline & 2990 & $\mathrm{M}$ as2(99) \\
\hline 2892 & 2901 & $\mathrm{CH}_{2}$ as(99) \\
\hline \multirow{2}{*}{2866} & 2874 & $M \operatorname{ss}(98)$ \\
\hline & 2874 & $\mathrm{M} s \mathbf{s s}(99)$ \\
\hline 2848 & 2839 & $\mathrm{CH}_{2} \mathrm{ss}(99)$ \\
\hline \multirow{2}{*}{1463} & 1455 & $\mathrm{Mab1}(71) \mathrm{CH}_{2} \mathrm{~b}(19)$ \\
\hline & 1449 & $\mathrm{M}$ ab2(89) \\
\hline 1454 & 1445 & M ab2(94) \\
\hline 1443 & 1444 & Mab1(88) \\
\hline 1427 & 1436 & $\mathrm{CH}_{2} \mathrm{~b}(73) \mathrm{M}$ ab1(21) \\
\hline \multirow{2}{*}{1382} & 1382 & $\mathrm{M} \mathrm{sb}(92)$ \\
\hline & 1375 & $\mathrm{M} \mathrm{sb}(93)$ \\
\hline 1443 & 1444 & $\mathrm{M} a b 1(88)$ \\
\hline \multirow[t]{2}{*}{1427} & 1436 & $\mathrm{CH}_{2} \mathrm{~b}(73) \mathrm{M}$ ab1(21) \\
\hline & 1382 & $\mathrm{M} \mathrm{sb}(92)$ \\
\hline \multirow[t]{2}{*}{1382} & & \\
\hline & 1375 & $\mathrm{M} \mathrm{sb}(93)$ \\
\hline 1333 & 1331 & $\mathrm{CH}_{2} \mathrm{w}(63)$ \\
\hline 1283 & 1289 & $\mathrm{CH}_{2} \operatorname{tw}(58) \mathrm{Mr} 2(13)$ \\
\hline 1146 & 1152 & $\operatorname{CCs}(45) \mathrm{M} r 1(31) \mathrm{CX}_{2} w(13) \mathrm{MC} s(12)$ \\
\hline 1091 & 1092 & $\mathrm{MC} s(48) \mathrm{M}$ r1(13) \\
\hline 1042 & 1048 & $\mathrm{CCs}(45) \mathrm{M} \mathrm{r2(18)} \mathrm{M} \mathrm{r1(14)}$ \\
\hline 1020 & 1019 & $\mathrm{CCs}(26) \mathrm{M} \mathrm{r} 2(32) \mathrm{CH}_{2} \mathrm{tw}(12)$ \\
\hline 1008 & 1005 & $\mathrm{Mr} 2(73) \mathrm{CH}_{2} \mathrm{tw}(11)$ \\
\hline 982 & 974 & $\mathrm{Mr1}(51) \mathrm{CH}_{2} \mathrm{w}(19) \mathrm{CCs}(12)$ \\
\hline 859 & 866 & $\operatorname{CCs}(48) \mathrm{Mr}$ r (34) \\
\hline 796 & 794 & $\mathrm{CH}_{2} \mathrm{r}(61) \mathrm{M} \mathrm{r} 2(45)$ \\
\hline 692 & 691 & $\mathrm{CX}_{2}$ as $(85) \mathrm{CX}_{2} \mathrm{r}(50) \mathrm{CH}_{2} \operatorname{def}(16)$ \\
\hline 567 & 569 & $\mathrm{CX}_{2} \operatorname{ss}(59) \mathrm{CX}_{2}$ as(17) $\mathrm{CX}_{2} \operatorname{def}(14) C \mathrm{X}_{2} \mathrm{~b}(10)$ \\
\hline 413 & 417 & $\mathrm{CX}_{2} \mathrm{w}(26) \mathrm{CX}_{2} \mathrm{ss}(18) \mathrm{CH}_{2} \operatorname{def}(16) \mathrm{CX}_{2}$ as(10) \\
\hline 367 & 362 & $\mathrm{CX}_{2} w(42) \mathrm{CX}_{2} \operatorname{def}(38)$ \\
\hline 358 & 358 & $\mathrm{CX}_{2} \mathrm{r}(38) \mathrm{CX}_{2} \mathrm{w}(13) \mathrm{CX}_{2}$ as $(11)$ \\
\hline 276 & 297 & $\begin{array}{l}\mathrm{CX}_{2} \operatorname{tw}(39) \mathrm{CX}_{2} \mathrm{~b}(20) \mathrm{CX}_{2} \operatorname{def}(16) \mathrm{CH}_{2} \operatorname{def}(16) \\
\quad \mathrm{CX} 2 \mathrm{ss}(10)\end{array}$ \\
\hline 276 & 275 & $\mathrm{MC}$ tor $(96)$ \\
\hline 252 & 259 & $\mathrm{CX}_{2} \mathrm{~b}(55) \mathrm{CX}$ tw(30) \\
\hline \multirow[t]{3}{*}{202} & 201 & $\mathrm{MC}$ tor $(88)$ \\
\hline & 180 & $\mathrm{CH}_{2} \operatorname{def}(34) \mathrm{CX}_{2} \operatorname{def}(33) \mathrm{CX}_{2}$ tw(30) $\mathrm{CX}_{2} \mathrm{r}(19)$ \\
\hline & 129 & $\mathrm{CC}$ tor $(82)$ \\
\hline
\end{tabular}

${ }^{*}$ From [7].

'See footnote* of Table 1.

closer to the observed band at $2930 \mathrm{~cm}^{-1}$, the same mode in the $\mathrm{G}$ conformer showed a larger deviation. We therefore did not modify the $\mathrm{CH}_{2}$ force constants, particularly since Fermi resonances influence this region [5].

The assignments of the other bands follow quite reasonably from the frequencies calculated from our force field for dichlorides. The major problem is in the region below $280 \mathrm{~cm}^{-1}$, and in particular with the $\mathrm{CCl}_{2}$ twist mode, calculated at 290 and observed at $276 \mathrm{~cm}^{-1}$ for the $T$ conformer and calculated at 297 and observed at $276 \mathrm{~cm}^{-1}$ for the $G$ conformer. These as well as the torsion assignments will need further study.

\section{2,2-Dichloropropane}

Many authors [9-12] have studied the vibrational spectrum of 2,2-dichloropropane. This molecule has high symmetry, $C_{2 v}$, and the modes divide into four symmetry species, 
$A_{1}, A_{2}, B_{1}$ and $B_{2}$. Each shows characteristic features in the vibrational spectrum, such as specific gas-phase band contours. These properties, and the group symmetry in the normal mode analysis, are useful in helping to assign the bands. However, there have still been some disagreements in the band assignments, primarily in the $A_{2}, B_{1}$ and $B_{2}$ species.

KLABOE [10] assigned the $1192 \mathrm{~cm}^{-1}$ band to the $A_{2}$ block because he observed it only in the Raman spectrum. However, Green and Harrison [11] and Berlandier et al. [12] observed peaks at this position also in the i.r.. GREEN and HARRISON [11] pointed out that the absorption at $1192 \mathrm{~cm}^{-1}$ persists weakly in the gas spectrum, with a shape that seems like a $C$-type contour. BerLandier et al. [12] observed that the $1192 \mathrm{~cm}^{-1}$ band was sharp in the liquid and broader in the gas. The above two studies suggest that the contour is of the $C$-type, which indicates that the band at $1192 \mathrm{~cm}^{-1}$ should be assigned to the $B_{1}$ species.

The band at $1121 \mathrm{~cm}^{-1}$ has an $A$-type contour according to Berlandier $e t$ al. and others $[10,11]$, implying that it should be assigned to the $B_{2}$ species. However, BERLANDIER et al. [12] also assigned this band to the $A_{2}$ species, although they noted that this may not be reliable. GREEN and HARRISON [11] assigned a $1018 \mathrm{~cm}^{-1}$ band, which may correspond to a $1012 \mathrm{~cm}^{-1}$ Raman band of BERLANDIER et al. [12], to the $A_{2}$ species. In view of these studies, we have assigned the band at $1012 \mathrm{~cm}^{-1}$ to the $A_{2}$ species, retaining the assignment of $1121 \mathrm{~cm}^{-1}$ to the $B_{2}$ species.

In the $B_{2}$ species, KLABOE [10] assigned the $1034 \mathrm{~cm}^{-1}$ band to the methyl rock mode. However, Berlandier et al. [12] could not observe a band at $1034 \mathrm{~cm}^{-1}$ and assigned this mode to a band at $1121 \mathrm{~cm}^{-1}$, which shifted to $1110 \mathrm{~cm}^{-1}$ in the liquid. GreEN and HARRISON [11] obtained a similar result.

Our work follows the assignments of BERLANDIER et al. [12], except for the $1012 \mathrm{~cm}^{-1}$ band in the $A_{2}$ block, and uses the liquid phase frequencies. The observed and calculated

Table 6. Obscrved and calculated frequencics of 2,2-dichloropropane

\begin{tabular}{|c|c|c|c|}
\hline Sym. & Observed & Calc. & Potential energy distribution* \\
\hline \multirow[t]{9}{*}{$A_{1}$} & 3000 & 2992 & $\mathrm{M}$ as(99) \\
\hline & 2937 & 2874 & $M \operatorname{ss}(100)$ \\
\hline & 1434 & 1446 & $\mathrm{Mab1}(93)$ \\
\hline & 1386 & 1386 & $\mathrm{M} \mathrm{sb}(90)$ \\
\hline & 1156 & 1156 & $\mathrm{Mrl}(47) \mathrm{MC} s(39) \mathrm{CX}_{2} \operatorname{def}(13) \mathrm{CX}_{2} \mathrm{ss}(111)$ \\
\hline & 910 & 903 & $\operatorname{MCs}(54) \mathrm{M} \mathrm{r1}(40)$ \\
\hline & 559 & 561 & $\mathrm{CX}_{2} \operatorname{ss}(66) \mathrm{CX}_{2} \operatorname{def}(11)$ \\
\hline & 362 & 362 & $\mathrm{CX}_{2} \operatorname{def}(61) \mathrm{CX}_{2} \mathrm{~b}(19)$ \\
\hline & 259 & 259 & $\mathrm{CX}_{2} \mathrm{~b}(75) \mathrm{CX}_{2} \operatorname{dcf}(33) \mathrm{CX}_{2} \mathrm{ss}(19)$ \\
\hline \multirow[t]{5}{*}{$A_{2}$} & 3003 & 2991 & $\mathrm{M}$ as2(99) \\
\hline & 1444 & 1442 & $\mathrm{Mab2(95)}$ \\
\hline & 1012 & 1004 & $\mathrm{M} \mathrm{r2(93)}$ \\
\hline & & 293 & $\mathrm{MC}$ tor(64) $\mathrm{CX}_{2} \mathrm{tw}(35)$ \\
\hline & 287 & 278 & $\mathrm{CX}_{2} \operatorname{tw}(63) \mathrm{MC}$ tor $(36)$ \\
\hline \multirow[t]{7}{*}{$B_{1}$} & 2988 & 2990 & $M$ as1(99) \\
\hline & 2935 & 2874 & $\mathrm{M} s \mathrm{~s}(100)$ \\
\hline & 1454 & 1442 & $\mathrm{M}$ ab1(94) \\
\hline & 1372 & 1367 & $M \operatorname{sb}(99)$ \\
\hline & 1188 & 1186 & $\mathrm{MC} \mathrm{s}(63) \mathrm{M} \mathrm{rl}(23) \mathrm{CX}_{2} \mathrm{w}(18)$ \\
\hline & 950 & 958 & M r1(69) MC s(25) \\
\hline & 389 & 388 & $\mathrm{CX}_{2} \mathrm{w}(84)$ \\
\hline \multirow[t]{6}{*}{$B_{2}$} & 3000 & 2991 & $\mathrm{M}$ as2(99) \\
\hline & 1444 & 1444 & $M a b 2(94)$ \\
\hline & 1110 & 1115 & $\mathrm{M} \mathrm{r2(77)} \mathrm{CX}_{2} \mathrm{r}(16) \mathrm{CX}_{2}$ as (11) \\
\hline & 656 & 653 & $\mathrm{CX}_{2}$ as $(97) \mathrm{CX}_{2} \mathrm{r}(44) \mathrm{M}$ r2(13) \\
\hline & 357 & 360 & $\mathrm{CX}_{2} \mathrm{r}(60) \mathrm{CX}_{2}$ as $(13)$ \\
\hline & & 268 & $\mathrm{MC} \operatorname{tor}(99)$ \\
\hline
\end{tabular}

\footnotetext{
* See footnote* of Table 1.
} 
Table 7. Force constants for 2,2-dichloropropane

\begin{tabular}{|c|c|}
\hline Force constant* & Value \\
\hline MH & 4.7522 \\
\hline MC & 4.2576 \\
\hline $\mathrm{CX}$ & 2.7433 \\
\hline НМН & 0.5397 \\
\hline $\mathrm{CMH}$ & 0.6433 \\
\hline $\mathrm{XCX}$ & 1.0200 \\
\hline MCX & 1.2696 \\
\hline $\mathbf{M C M}^{\dagger}$ & 0.7714 \\
\hline M.C & 0.1410 \\
\hline МH,MH & 0.0010 \\
\hline $\mathbf{M C}, \mathbf{M}^{\prime} \mathbf{C}^{\dagger}$ & 0.3919 \\
\hline $\mathrm{MC}, \mathrm{CX}$ & 0.4524 \\
\hline $\mathrm{CX}, \mathrm{CX}$ & 0.3644 \\
\hline СМ,СMH & 0.1510 \\
\hline $\mathrm{MC}, \mathrm{MCX}$ & 0.0998 \\
\hline $\mathrm{MC}, \mathrm{XCM}^{\prime}$ & -0.0985 \\
\hline 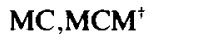 & 0.0104 \\
\hline $\mathrm{CX}, \mathrm{MCX}$ & 0.4052 \\
\hline $\mathrm{CX}, \mathrm{X}^{\prime} \mathrm{CM}$ & -0.0893 \\
\hline $\mathrm{CX}, \mathrm{MCM}^{+}$ & 0.1403 \\
\hline $\mathrm{CX}, \mathrm{XCX}$ & 0.2099 \\
\hline НМН,НМН & 0.0091 \\
\hline HMH,CMH & 0.0182 \\
\hline CMH,CMH & -0.2120 \\
\hline $\mathrm{MCX}, \mathrm{XCX}$ & -0.1824 \\
\hline $\mathrm{MCX}, \mathrm{XCM}^{\prime *}$ & 0.1203 \\
\hline $\mathrm{MCX}, \mathrm{MCX}^{\prime \dagger}$ & -0.1826 \\
\hline $\mathrm{MCX}, \mathrm{X}^{\prime} \mathrm{CM}^{\prime \dagger}$ & 0.0129 \\
\hline$(\mathrm{HMC}, \mathrm{MCX})_{\mathrm{T}}$ & -0.0568 \\
\hline$(\mathrm{HMC}, \mathrm{MCX})_{\mathrm{G}}$ & -0.0617 \\
\hline$(\mathrm{MCM}, \mathrm{CMH})_{\mathrm{r}}^{\dagger}$ & -0.1642 \\
\hline$(\mathrm{MCM}, \mathrm{CMH})_{\mathrm{G}}{ }^{\dagger}$ & -0.1684 \\
\hline$(\mathrm{M} . \mathrm{C})(\mathrm{C} \cdot \mathrm{M})^{\dagger}$ & 0.0080 \\
\hline \multicolumn{2}{|c|}{$\begin{array}{l}\text { chlorine, } \mathrm{AB}=\mathrm{AB} \text { bond } \\
\text { stretch, } \mathrm{ABC}=\mathrm{ABC} \text { angle } \\
\text { bend, } \mathrm{A} . \mathrm{B}=\mathrm{AB} \text { torsion. } \\
\text { Units: mydn/ } \AA \text { for stretch and } \\
\text { stretch-stretch; mdyn for } \\
\text { stretch-bend; mdyn } \AA \text { for all } \\
\text { other force costants. } \\
+ \text { Unique force constants }\end{array}$} \\
\hline $\begin{array}{l}\text { defined fo } \\
\text { dichloropropane. }\end{array}$ & 2,2 \\
\hline
\end{tabular}

frequencies are listed in Table 6, with the PEDs. The force constants for 2,2dichloropropane are given in Table 7 , and are the result of a least squares refinement that includes 2,2,3-TCB, 2,2-DCB and 2,2-DCPr. Thus, the 23 observed frequencies of 2,2DCPr are used to fit 11 unique force constants in this molecule (see Table 7), the other 22 force constants (not unique to 2,2-DCPr) being part of the overall refinement involving 2,2-DCB and 2,2,3-TCB as well as 2,2-DCPr. The calculated frequencies agree well with the observed bands, except for the $M$ ss modes in the $A_{1}$ and $B_{1}$ blocks. Throughout the refinement these modes were given zero weight.

\section{CONCLUSIONS}

We have synthesized 2,2,3-trichlorobutane and analysed its i.r. and Raman spectra in terms of normal mode calculations. These were based on a force field for secondary 
dichlorides co-refined together with 2,2-dichlorobutane and 2,2-dichloropropane. In the latter case, we have re-examined the band assignments and we present a force field specific to this molecule.

The agreement between observed and calculated frequencies is quite good: the average error for three conformers of $2,2,3$-trichlorobutane is $5.2 \mathrm{~cm}^{-1}$, for two conformers of 2,2-dichlorobutane it is $6.2 \mathrm{~cm}^{-1}$, and for 2,2-dichloropropane it is $4.3 \mathrm{~cm}^{-1}$. The overall average error for these three molecules is $5.4 \mathrm{~cm}^{-1}$. This force constant set is therefore a good component of a comprehensive force field for multiply-chlorinated hydrocarbons [3].

Acknowledgements - This research was supported by the Polymers Program of NSF, grant DMR-8806975, and by a Macromolecular Research Center fellowship to one of us (S.H.C.).

\section{REFERENCES}

[1] S. H. Chough and S. Krimm, Spectrochim. Acta 46A, 1405 (1990).

[2] M. S. Wu, P. C. Painter and M. M. Coleman, Spectrochim. Acta 35A, 823 (1979).

[3] S. H. Chough and S. Krimm, Spectrochim. Acta 46A, 1431 (1990).

[4] H. D. Scharf and F. Laux, Synthesis 582 (1970).

[5] R. G. Snyder, S. L. Hsu and S. Krimm, Spectrochim. Acta 34A, 395 (1978).

[6] X. Jing and S. Krimm, Spectrochim. Acta 39A, 251 (1983).

[7] K. Ohno, Y. Shiro and H. Murata, Bull. Chem. Soc. Jap. 47, 2962 (1974).

[8] G. A. Crowder and W. Lin, J. Molec. Struct 62, 1 (1980).

[9] M. C. Tobin, J. Am. Chem. Soc. 75, 1788 (1953).

[10] P. Klaboe, Spectrochim. Acta 26A, 977 (1970).

[11] J. H. S. Green and D. J. Harrison, Spectrochim. Acta 27A, 1217 (1971).

[12] P. G. Berlandier, J. L. Bribes and R. G. V. Tabacik, J. Chim. Phys. 75, 202 (1978). 